\title{
The Lancet-0'Neill Institute/Georgetown University Commission on Global Health and Law: The Power of Law to Advance the Right to Health
}

\author{
Jenny Kaldor \\ School of Law, University of Tasmania, Hobart, TAS, Australia \\ Lawrence O. Gostin \\ Georgetown University - Law Center - O'Neill Institute for National and Global Health Law, \\ gostin@law.georgetown.edu \\ John T. Monahan \\ Office of the President, Georgetown University, John.Monahan@georgetown.edu \\ Katie Gottschalk \\ O'Neill Institute for National and Global Health Law, Georgetown University Law Center, \\ kcg35@georgetown.edu
}

This paper can be downloaded free of charge from:

https://scholarship.law.georgetown.edu/facpub/2355

https://ssrn.com/abstract=3784683

Public Health Ethics, Vol. 13, Issue 1, Pp. 9-15.

This open-access article is brought to you by the Georgetown Law Library. Posted with permission of the author. Follow this and additional works at: https://scholarship.law.georgetown.edu/facpub

Part of the Health Law and Policy Commons, and the International Humanitarian Law Commons 


\title{
The Lancet-O'Neill Institute/Georgetown University Commission on Global Health and Law: The Power of Law to Advance the Right to Health
}

\author{
Jenny C. Kaldor $\mathbb{D}^{*}$, Faculty of Law, The University of Tasmania \\ Lawrence O. Gostin, O'Neill Institute for National and Global Health Law, Georgetown \\ University
}

John T. Monahan, Georgetown University Global Health Initiative, Georgetown University
Katie Gottschalk, O'Neill Institute for National and Global Health Law, Georgetown University

*Corresponding author: Jenny C. Kaldor, Faculty of Law, The University of Tasmania, Sandy Bay 7005 TAS, Australia. Tel.: +61 362268335 ; Email:
jenny.kaldor@utas.edu.au

The Lancet-O'Neill Institute/Georgetown University Commission on Global Health and Law published its report on the Legal Determinants of Health in 2019. The term 'legal determinants of health' draws attention to the power of law to influence upstream social and economic influences on population health. In this article, we introduce the Commission, including its background and rationale, set out its methodology, summarize its key findings and recommendations and reflect on its impact since publication. We also look to the future, making suggestions as to how the global health community can make the best use of the Commission's momentum in relation to using law and legal tools to advance population health.

\section{Introduction}

The past decade has seen exponential growth in research and action at the intersection of law and the health of populations, both nationally (Burris et al., 2016; Gostin and Wiley, 2016) and worldwide (Gostin, 2014). While law has long been recognized as critical to major public health achievements, it remains relatively underutilized, and less well understood, compared with other public health disciplines such as medicine and epidemiology. Yet, with an increasingly complex global health landscape-characterized by the triple burden of infectious diseases, noncommunicable diseases (NCDs) and injuries, as well as numerous and overlapping global health institutions-the importance of mapping and evaluating law to improve health has never been greater.
With a mandate to examine the vital role of law in responding to global health challenges and to make recommendations to improve health outcomes, the LancetO'Neill Institute/Georgetown University Commission on Global Health and Law issued its report in 2019. The Commission brought together an interdisciplinary team of global leaders in the fields of health, law and governance, with backgrounds in academia, government, non-governmental organizations and global health institutions. The Commission's report, The Legal Determinants of Health: Harnessing the Power of Law for Global Health and Sustainable Development (the Report) offers a blueprint for using law as a tool to advance the right to health (Gostin et al., 2019a).

In this article, we reflect on the Commission's work, including its rationale, key findings and recommendations. We begin by examining the intersection of law and 
health, in order to underscore the role of law in advancing the right to health. We then summarize the Report's main findings, organized according to four overarching 'legal determinants of health' - a term coined by the Commission to demonstrate that laws, and the rule of law, are major upstream influences on health. Our four legal determinants show the key pathways through which law can powerfully influence global health outcomes, whether positively or negatively. The legal determinants highlight opportunities for reform, which we turn to in our final sections, as we review the Commission's recommendations and look to the future.

\section{Background: The Rationale and Importance of the Commission}

Though not always visible, law is pervasive. Our livesand thus our health-are structured by instruments such as treaties, statutes and regulations that express public policy, as well as by the public institutions (e.g., courts, legislatures and agencies) responsible for creating, implementing and interpreting the law. The use of law was central to many of the signal social reforms of the Victorian and Progressive eras, including those relating to food, sanitation and industrial safety. Law also played a critical role throughout the 20th century to deliver safe and effective medicines and vaccines, to establish healthcare systems, and to improve the built and natural environments.

As we describe in more detail below, despite major improvements to health outcomes in recent decades, there remain profound health inequalities both within and between countries. For example, while reductions in human immunodeficiency virus (HIV) prevalence have been a major success story of the past two decades, such reductions were relatively rapid for the wealthiest 60 per cent of people, while the poorest 40 per cent made little gains (Wagstaff et al., 2014).

In 2020, the challenge for those working in the field of public health law is to articulate a coherent and, importantly, actionable vision of how law can advance the vision of global health with justice. Moreover, with the growing use of both national and international law to address new challenges such as pandemics and NCDs (Gostin et al., 2017), articulating this vision has never been more important.

To improve population health, and to do so in a way that is fair and equitable, what kinds of laws should countries implement? How should they be implemented-through what processes, and based on what kinds of evidence? Which populations stand to benefit from new laws, and which populations are being harmed by old-fashioned or out-of-date laws? These are the kinds of questions that motivated the work of the Commission, and which we sought to address in the Report.

\section{Process and Approach of the Commission}

The Commission was constituted of 15 experts, with experience across a range of global health sectors and from diverse countries. Throughout 2015 and 2016, the Commissioners conducted a series of meetings and workshops, to determine broad themes and specific case studies. They were supported in this work by a secretariat, researchers and writing staff at the O'Neill Institute. As noted in the Report, its intent was not to offer a systematic review of the field. Rather, we sought to enunciate core legal concepts, illustrated with salient case studies. Perhaps most importantly, and at the urging of the health professionals on the Commission, we sought to advocate for the value of law in improving global health with justice. In line with these purposes, the Report begins by offering a 'primer' on law for a public health audience. This included definitions and introductions to law (domestic, international and the relationship between the two), the rule of law, the right to health and the different functions of law. It also introduced the key players in global health-the main subjects of law.

\section{The 'Legal Determinants of Health' Framing}

The fields of global health and the law are vast, complex and constantly evolving. Moreover, both law and global health can be defined narrowly or broadly: for example, global health is not only limited to diseases and injuries, but also encompasses broader ideas such as violence and conflict, mass migration and climate change (Gostin et al., 2019b). In order to make sense of this complexity and to ensure the ongoing relevance of the Report's message, the Commission identified cross-cutting themes, which we described as the legal determinants of health. This choice of framing had three main aims. First, by embracing the concept of 'determinants', the Commission sought to situate law within the larger social determinants of health (SDoH) movement (Baum, 2008; Burris, 2011). An SDoH lens draws attention to the myriad influences on health outcomes: not just the proximal causes of injuries and disease, but also the more 
distal ones, which include economic, social and environmental factors shaped powerfully by law.

This in turn ties into the second aim, which was to engage doctors, scientists and other public health professionals (i.e., the traditional Lancet audience) with a concept of law that is broader than rules, regulations and litigation. As discussed below, one of the Report's messages relates to the importance of building stronger bridges between the legal and health communities of scholarship and practice. The Legal Determinants of Health framework was a way of moving beyond a narrow concept of 'law as umpire', to rather understand how law affects health in multiple ways across countries and sectors.

Finally, the concept of determinants is a neutral one, which recognizes that the practical effect of law on health is not unidirectional, and may be positive, negative or mixed. While law can advance health and justice for communities and individuals, it can also undermine them, for example, by violating human rights. A lens that is attentive to all dimensions of this relationship reveals opportunities for reflection and law reform.

\section{Key Themes and Findings}

\section{Legal Determinant 1: Law Can Translate Vision into Action on Sustainable Development}

This legal determinant speaks to the power of law to set norms and standards, translating broad, visionary principles into concrete actions. In 2015, the United Nations (UN) adopted its 2030 Agenda for Sustainable Development (United Nations, 2015). It is comprised of 17 interconnected Sustainable Development Goals (SDGs), which are intended to address global challenges such as climate change, poverty, inequality and conflict. The central health-related goal is Goal 3, 'ensure healthy lives and promote well-being for all at all ages' (United Nations 2015)—although health is also closely connected to a number of other goals, including Goal 1 (poverty), Goal 2 (food and nutrition security), Goal 6 (water and sanitation) and Goal 13 (climate). The SDG's vision of health is not a static endpoint; rather, it is the goal of healthy active living throughout the lifespan. In the Report, we proposed that law could play a critical role in implementing the SDGs, and we illustrated this through the case study of universal health coverage (UHC).

The SDGs promise to 'leave no one behind' in the coming decade, and health equity will be critical to achieving the promise of sustainable development (United Nations, 2015). Currently, at least half the world's population lacks full coverage for essential health services (United Nations, 2019), eroding health and equity and posing a significant barrier to sustainable development. One study, for example, showed that under the Millennium Development Goals (MDGs, predecessors to the SDGs), the poorest 40 per cent were doing worse than before on MDG health outcomes in one-quarter of 64 countries surveyed. Without significant reforms, many countries will not close core health equity gaps this century, much less achieve the commitment to leave no one behind by 2030 (Friedman et al., 2019).

Law provides both the mandate for UHC, and the tools to achieve it, through a range of frameworks and mechanisms. Law can provide a strong foundation for all key aspects of UHC, including true universality in coverage, equity and quality —all without impoverishing people for gaining access to health coverage. For example, no health system can be regarded as 'universal' if it does not protect vulnerable people (e.g., unlawful migrants) from service denial or discrimination. As described further below, since the report was finalized, Commission institutions have partnered with key international organizations to form a new project called Legal Solutions for UHC (Gostin et al., 2020).

\section{Legal Determinant 2: Law Can Be Used to Strengthen the Governance of National and Global Health Institutions}

This legal determinant relates to the relationship between law and governance, i.e., ' $\mathrm{t}$ ] he complex of formal and informal institutions, mechanisms, relationships and processes between and among states, markets, citizens and organizations ... through which collective interests on the global plane are articulated, rights and obligations are established, and differences are mediated' (Ottersen et al., 2014). The Commission identified a series of systemic weaknesses in the governance of global health, which pose enormous challenges to both health and justice: the fragmented and overlapping mandates of global health institutions, countries' poor compliance with international norms and standards, and the mismatch between the extant global governance regime and the recent proliferation of new players in global health.

In response, we proposed a number of ways in which law can be used to address these weaknesses. At both the national and international levels, one of the core functions of law is to establish, structure and govern public and private institutions: for instance, creating institutions (e.g., nation states and corporations) and establishing their mandates (e.g., constitutions and articles of 
incorporation), thus defining the scope and reach of their activities. Law can be used to clarify the respective roles and authorities of global health institutions, to set ground-rules, to adjudicate disputes, and to impose higher levels of transparency and accountability.

\section{Legal Determinant 3: Law Can Be Used to Implement Fair, Evidence-based Health Interventions}

One of the reasons why law can be such a powerful tool of public health is that, once implemented, laws and regulations can lower the overall exposure to risk factors, and thus affect the health of entire populations (Rose, 1992). This is particularly important given the changing profile of health and disease, which is today dominated by risks that are not bound by borders, and which have common underlying causes (GBD 2015 Mortality and Causes of Death Collaborators, 2016).

We drew on research and scholarship, as well as recommendations by pre-eminent global health institutions such as the World Health Organization (WHO), to describe ways in which law could be used as a tool to implement fair, evidence-based interventions across the three domains of infectious diseases, NCDs and injuries. While some of these interventions have a long history (e.g., isolation and quarantine), others are highly innovative, such as the use of taxation to improve population diets and prevent chronic disease. We focused on interventions with a strong evidence base, as well as those which are likely to be highly cost-effective. At the same time, we highlighted instances where legal interventions have in fact undermined health with justice, by stigmatizing and marginalizing already-vulnerable populations-the criminalization of drug use being a prime example. We argued that the goal is to deploy the best evaluative evidence to adopt, reform or repeal laws so that they are effective in meeting health challenges, while minimizing harms.

\section{Legal Determinant 4: Building and Strengthening Legal Capacities for Health}

Our fourth legal determinant relates to strengthening legal capacity within countries, in order to facilitate the best use of law to improve population health. This is because best-practice recommendations-including those articulated in legal determinants 1-3-are meaningless unless countries are empowered with the legal infrastructure to implement them. Capacity building requires many strengths at the local and national levels, including health and research expertise, a competent well-trained workforce and adequate and fair financing of health services. Capacity also requires strong institutions, legislatures, courts and civil society all versed on law and health, well-prepared to assure all the legal determinants of health.

We identified three important aspects of legal capacity building for health: building and maintaining strong legal environments (i.e., the infrastructure for drafting, implementing and enforcing laws that promote health with justice), developing a robust and credible evidence base for legal interventions and building bridges between the legal and health communities in order to achieve a transdisciplinary workforce. For each of these, there are practical steps that governments, international organizations, funders, non-governmental organizations and academics can take to help countries to develop their legal capacity-from ensuring public participation in legislative and policy processes, to funding and carrying out evaluations of innovative health laws, to establishing opportunities for interdisciplinary collaboration and professional development.

\section{Recommendations of the Commission}

Flowing from the identified legal determinants of health, the Commission made seven recommendations for action, relating to legal instruments, legal capacities and institutional reforms. These recommendations were aimed at national governments and international health institutions, and are listed in Table 1, alongside their corresponding Legal Determinant.

\section{Progress since the Commission and Moving Forward}

Since the launch of the Report in May 2019, the Commissioners have been working with The Lancet and other partners to make the best use of the Report's momentum and to drive forward the work of the Commission. In order to share the Report and convene stakeholders, we have co-hosted launches, including in Washington DC, New York, London (the launch at Chatham House featured the Chief Justice of the UK), Bristol and Edinburgh, and at the headquarters of the Joint United Nations Programme on HIV and acquired immunodeficiency syndrome (AIDS) (UNAIDS) in Geneva.

As mentioned above, one of the most notable developments has been the launch, in September 2019, of the 
Table 1. Recommendations of the Commission

\begin{tabular}{|c|c|c|}
\hline Legal determinant & Recommendation & $\begin{array}{l}\text { Who must take } \\
\text { action? }\end{array}$ \\
\hline $\begin{array}{l}\text { Translating vision } \\
\text { into action on } \\
\text { sustainable } \\
\text { development }\end{array}$ & $\begin{array}{l}\text { 1. Set standards to support the implementation of, and objectively } \\
\text { evaluate compliance with, SDG } 3.8 \text { on UHC, as well as the UN General } \\
\text { Assembly's political declaration of the high-level meeting on UHC } \\
\text { (United Nations, 2019) } \\
\text { 2. Strengthen or create a legal framework, such as a constitutional or } \\
\text { statutory right to health, to ensure rights-based UHC on the basis of } \\
\text { principles of equity and non-discrimination, including affordability, } \\
\text { financial protection, transparency, accountability, participation, } \\
\text { privacy and sustainable financing }\end{array}$ & $\begin{array}{l}\text { The UN, WHO } \\
\text { and inter- } \\
\text { national } \\
\text { partners } \\
\text { National } \\
\text { governments }\end{array}$ \\
\hline $\begin{array}{l}\text { Strengthening the } \\
\text { governance of } \\
\text { national and glo- } \\
\text { bal health } \\
\text { institutions }\end{array}$ & $\begin{array}{l}\text { 3. Safeguard the public's health and safety through the creation or } \\
\text { adoption of good governance standards, embracing the highest } \\
\text { principles of equity, inclusive participation, transparency and } \\
\text { accountability } \\
\text { 4. Develop legal frameworks that establish principles of good governance } \\
\text { throughout national health systems and policy making, form a } \\
\text { country-appropriate mechanism to advise on legal interventions with } \\
\text { high health impact, and adopt legislation requiring health impact } \\
\text { assessments for policies, programmes and projects that might ser- } \\
\text { iously affect health }\end{array}$ & $\begin{array}{l}\text { The UN, WHO } \\
\text { and inter- } \\
\text { national } \\
\text { partners } \\
\text { National } \\
\text { governments }\end{array}$ \\
\hline $\begin{array}{l}\text { Law can be used to } \\
\text { implement fair, } \\
\text { evidence-based } \\
\text { health } \\
\text { interventions }\end{array}$ & $\begin{array}{l}\text { 5. Increase WHO's legal capacity, to enable it to spearhead development } \\
\text { of a global evidence base for public health laws and to support the } \\
\text { enactment and implementation of national and global health laws that } \\
\text { are effective and sustainable }\end{array}$ & $\begin{array}{l}\text { WHO, national } \\
\text { govern- } \\
\text { ments, foun- } \\
\text { dations and } \\
\text { civil society }\end{array}$ \\
\hline $\begin{array}{l}\text { Building legal cap- } \\
\text { acity for health }\end{array}$ & $\begin{array}{l}\text { 6. Build national capacities to enact and effectively implement public } \\
\text { health laws } \\
\text { 7. Partner with legal and health experts to create an independent } \\
\text { standing commission on global health and the law that would advance } \\
\text { the health-related SDGs by proposing evidence-based legal interven- } \\
\text { tions for addressing major global health challenges, reforms of the } \\
\text { global health architecture and international law, and strategies to } \\
\text { build and strengthen global and national health law capacities }\end{array}$ & $\begin{array}{l}\text { National } \\
\text { governments } \\
\text { The Lancet and } \\
\text { WHO }\end{array}$ \\
\hline
\end{tabular}

UHC Legal Solutions Network on the margins of the UN General Assembly's adoption of its first political declaration on UHC. This is a new collaboration between WHO, the United Nations Development Programme, UNAIDS, the Inter-Parliamentary Union and Georgetown University. Its aim is to support national policymakers to realize UHC through crafting and implementing laws, regulations and policies that provide financial protection and advance equity (Gostin et al., 2020). The Network will leverage the strengths of all its partner organizations and assist countries by helping to scale up essential legislative capacities, share good practice, raising awareness and produce drafting toolkits for ministries, parliamentarians and civil society. The timing of this launch is propitious, as numerous countries are currently debating establishing or improving UHC programmes. At the same time, debating UHC legislation may also raise awareness about, and provide opportunities to address, laws that affect other SDOHs, such as agriculture, housing, the built environment, and so on.

\section{Conclusions}

Law is a powerful determinant of health outcomes for people everywhere-yet, to date it has been an underutilized tool for improving global health. The goal of the Commission was to make a strong case for the role of law 
in helping to fulfil the right to health, support sustainable development and achieve health with justice. To that end, we identified critical challenges in global health, and ways in which law could be used to address these, from specific legal interventions to broad governance principles. Our recommendations provide a means to build on the work presented in the Report, to guide and support countries and international institutions to make better use of law to advance the right to health. As we note above, some of these recommendations are already being put into practice, through the creation of innovative partnerships supporting countries in practical ways to undertake law reform.

Achieving global goals for health-including UHC, migrant health and the SDGs-will require hard work and sustainable financing. Beyond achieving vastly improved health outcomes (e.g., in maternal/child health and survival, vaccination and epidemic/endemic diseases), health equity or its lack, may well be the defining narrative of the 21 st century. Closing what are currently cavernous health inequalities will require the global health community to concentrate on a bold vision: health with justice. This does not just mean that health goods and services must be more fairly distributed. It also demands that we actively plan to focus on inequalities. It means mobilizing all government sectors beyond the health sector. And it means tackling the root causes of ill-health, such as poverty, discrimination and violence. Law and the legal determinants of health are crucial elements in that global project.

\section{Conflict of Interest}

All the authors were authors on the report of the LancetO'Neill Commission (the subject of this article). Gostin and Monahan were Co-Chairs of the Lancet-O'Neill Commission.

\section{References}

Baum, F. (2008). The Commission on the Social Determinants of Health: Reinventing Health Promotion for the Twenty-First Century? Critical Public Health, 18, 457-466.

Burris, S. (2011). Law in a Social Determinants Strategy: A Public Health Law Research Perspective. Public Health Reports, 126, 22-27.

Burris, S., Ashe, M., Levin, D., Penn, M., and Larkin, M. (2016). A Transdisciplinary Approach to Public Health Law: The Emerging Practice of Legal
Epidemiology. Annual Review of Public Health, 37, 135-148.

Friedman, E. A., Gostin, L. O., Kavanagh, M. M., Periago, M. R., Marmot, M., Coates, A., Binagwaho, A., Mukherjee, J., Chowdhury, M., Robinson, T., Veloso, V. G., Wang, C., and Were, M. (2019). Putting Health Equity at Heart of Universal Coverage- The Need for National Programmes of Action. BMJ, 367, 15901.

GBD 2015 Mortality and Causes of Death Collaborators

(2016). Global, Regional, and National Life Expectancy, All-Cause Mortality, and Cause-Specific Mortality for 249 Causes of Death: A Systematic Analysis for the Global Burden of Disease Study 2015. The Lancet, 388, 1459-1544.

Gostin, L. O. (2014). Global Health Law. Cambridge, MA: Harvard University Press.

Gostin, L. O., Blagojevic, A., Bland, S., Dhaliwal, M., Guerra, R., and Monahan, J. T. (2020). Launching the Universal Health Coverage Legal Solutions Network. The Lancet, 395, 112-113.

Gostin, L. O., DeBartolo, M. C., and Katz, R. (2017). The Global Health Law Trilogy: Towards a Safer, Healthier, and Fairer World. The Lancet, 390, 1918-1926.

Gostin, L. O., Monahan, J. T., Kaldor, J., DeBartolo, M., Friedman, E. A., Gottschalk, K., Kim, S. C., Alwan, A., Binagwaho, A., Burci, G. L., Cabal, L., DeLand, K., Evans, T. G., Goosby, E., Hossain, S., Koh, H., Ooms, G., Roses Periago, M., Uprimny, R., and Yamin, A. E. (2019a). The Legal Determinants of Health: Harnessing the Power of Law for Global Health and Sustainable Development. The Lancet, 393, 1857-1910.

Gostin, L. O., Monahan, J. T., Kaldor, J., and Friedman, E. A. (2019b). Global Health, Human Rights, and the Law: Authors' Reply. The Lancet, 394, 1988.

Gostin, L. O. and Wiley, L. F. (2016). Public Health Law: Power, Duty, Restraint, 3rd edn. Oakland: University of California Press.

Ottersen, O. P., Dasgupta, J., Blouin, C., Buss, P., Chongsuvivatwong, V., Frenk, J., Fukuda-Parr, S., Gawanas, B. P., Giacaman, R., Gyapong, J., Leaning, J., Marmot, M., McNeill, D., Mongella, G. I., Moyo, N., Møgedal, S., Ntsaluba, A., Ooms, G., Bjertness, E., Lie, A. L., Moon, S., Roalkvam, S., Sandberg, K. I., and Scheel, I. B. (2014). The Political Origins of Health Inequity: Prospects for Change. The Lancet, 383, 630-67.

Rose, G. A. (1992). The Strategy of Preventive Medicine. Oxford: Oxford University Press. 
United Nations (2015). Resolution Adopted by the General Assembly on September 25, 2015: 71/1 Transforming Our World: The 2030 Agenda for Sustainable Development. Geneva: United Nations.

United Nations (2019). Political Declaration of the High-Level Meeting on Universal Health Coverage: "Universal Health Coverage: Moving Together to Build a
Healthier World", Resolution Adopted by the General Assembly on 10 October 2019, $A / R E S / 74 / 2$. New York: United Nations.

Wagstaff, A., Bredenkamp, C., and Buisman, L. R. (2014). Progress on Global Health Goals: Are the Poor Being Left behind? The World Bank Research Observer, 29, 137-162. 